Amin Salih Mohammed, Saravana Balaji B., Hiwa Abdulkarim Mawlood

Lebanese French University, Erbil, Kurdistan Region, Iraq

\title{
CONCEPTUAL ANALYSIS OF IRIS RECOGNITION SYSTEMS
}

\begin{abstract}
Biometric is a reliable measurable physical feature as passwords. A biometric framework automatically provides evidence of an individual's identity based on the individual's unique features. Iris recognition is one of the physiological ways used to identify a person in the group and is one of the accurate biometric systems. This paper deals briefly about the surveys those done before about Iris recognition system and its benefits and uses in information technology and security fields. The use of low-cost equipment can help to make iris recognition other standards in security contexts, as the requirements for a secure identification are walking. As human Iris gives a phenomenal design for identification. In recent year, the acquisition, rehabilitation, quality assessment, compression of the image, divisions, noise reduction, normalization, removal of features, iris code match, large-size data base searching, applications, evaluation, performance in different conditions, and multi biometrics have been developing irises recognition in several active fields of research. This research gives at the background of iris recognition and literature of methods in various fields.
\end{abstract}

Keywords: human Iris; biometric; security; authentication; Iris recognition.

\section{Introduction}

Biotechnology is now a topic of research because of its high reliability and its ability to identify human beings. Biometric applications identify a person based on his behavior or physical characteristics. Physical characteristics include fingerprints, palm printing, hand geometry and iris patterns, or behavioral characteristics (such as typing patterns and handwritten signatures) which contain unique information about an individual. This type of ID technology is better than password, PIN, or anything else. Biometric technology can be used and applied for verification and reliable identification such as access control for sensitive and restricted areas, controlling passengers in airports and terminals, access to warehouses, access to server rooms and data center room [1], passing between borders and many other purposes. Until now, most of the iris has concentrated on entire and clean iris photos. The image's quality should influence the recognition or authentication of the iris. Fewer authentications of iris systems considered from a distance, the moving images those captured under very low light and of poor quality of iris taken from the camera definitely destroy or affects the performance of iris authentication or identification [2].

Literature review. Before the iris was recognized, the iris is locating by using landmark features. These characteristics and the specific state of the iris include imagery, separation and extraction. Limitation of the iris is a critical advance in iris acknowledgment in light of the fact that, whenever done inappropriately, resultant clamor (e.g., eyelashes, reflections, understudies, and eyelids) in the picture may lead to poor execution. The concept of use of iris patterns to identify an individual was suggested by the Frank Burch, ophthalmologist in 1939 [3]. In 1985, the concept of no two irises are similar was proposed by both Drs. Aran Safir and Leonard Flom, ophthalmologists. In 1987, and both Drs. Aran Safir and Leonard Flom were awarded the iris identification concept patent. Dr. Flom had approached Dr. John Daugman to make an iris identification of human algorithm. In 1994, the Defense Nuclear Agency started testing and providing a prototype unit, completed by 1995 , due to combined efforts, Dr. Daugman, and Drs. Flom Safir. In 1994, Dr. Daugman obtained a patent for his automated algorithms for iris recognition [4]. The first products commercially released in 1995. The broad patent covering the principle of iris recognition ended in 2005, providing marketing opportunities for other companies those have made their own iris recognition algorithms. The patent developed and implemented by Dr. Daugman on the implementation of IrisCodes $\left({ }^{\circ}\right.$ recognition did not expire until 2011 [5].

\section{Biometric Technology}

Biometrics are the automated using, for determinate identification or verification of the physiological or behavioral characteristics. Various aspects of this definition need to be developed. Every biometric identifier scan is divided into two groups:

1) physiological;

2) behavior.

Biometrics are depending on measuring the distinctive physiological and behavioral properties of biometrics. The physiological biometrics, based on direct measured parts of the human body, are considered physical-scan, face-scan, iris-scan, man-scan, and retina skirting. Signing and voice scanning are considered as behavioral biometrics, based on measures and data derived from an activity and therefore indirectly measuring human body characteristics. For behavioral biometry, the element of time is essential, and the characteristics measured are related, with a beginning and end, to actions such as spoken or signed words. Physiological/compatible classification is a useful way to view biometrics, since certain performance and privacy factors often differ among two types of biometrics. However, the distinction between conduct and physiology is what artificial. Behavioral biometrics is partly based on physiology, for example the shape or skill of the hands and fingers in the signature- scan of vocal cords in a vocal-scan. The way the user presents a finger or looks at a camera, for example, is likewise 
influenced by physiological biometric technology.

The biometric system is working by following below steps :

a) catching an example of exceptional element;

b) changing the example utilizing couple of numerical models into biometric format;

c) this biometric arrangement will give an institutionalized, effective, and significantly isolating depiction of highlight;

d) examination with different layouts to decide personality.

Depending on the element used, a decent biometric is described ; completely unique, so that there is no possibility for a pair of persons of similar characteristics - so that over time the feature remains fluid and is adequately acquired - to provide the user with adequacy and prevent dispersion of the feature.

\section{The Human Iris}

Iris is the eye's pigmented area. This is a muscly circular diaphragm, which separates the two eye regions. It stretches across the eyeball from the ciliary muscle before the lens. The light enters the eye, which is called a pupil, through a small circular opening in the middle. The iris checks the light that enters the eye when the eyes are tightened or relaxed, and thus the pupil contracts or dilates. Fig. 1, describes Eye external part containing Iris.

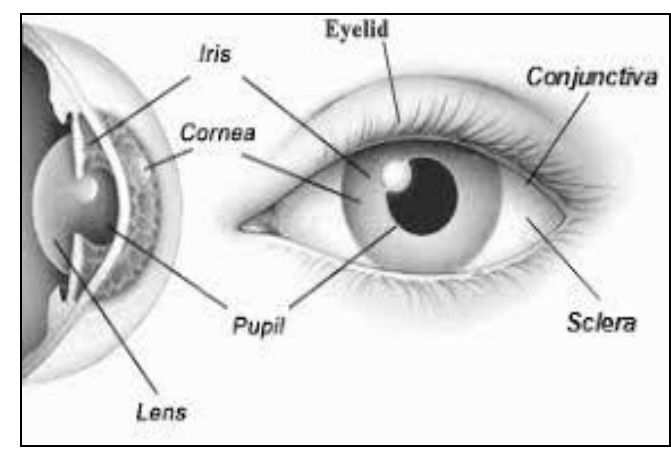

Fig. 1. Human Iris

During the elementary lifetime the particular pattern in the iris region is established and stromal pigmentation is carried out in a few years. There are no genetic factors to the incidental process of forming the unicular patterns of the iris. A pigment of the iris and the color of the eye is the only feature which relies on ancestral genes. As a result, the two eyes of an individual are autonomously independent. In addition, the same twins gain non-German iris patterns.

\section{Iris Recognition}

Iris Recognition also known as is a biometric automatic way for the using of the iris of human floral patterns for identifying and verifying humans. There are demands for Iris recognition in various areas like access controlling as well as security of the border, etc. is increasing regularly because of iniquity features such as rounds, ridges, furrows, complex patterns, freckles. It therefore presents an enormous level of randomness. The iris recognition's key advantage, in addition, of the iris recognition speed during matching and its extreme resistance to false matches is the constancy of the iris as, protected, an internal but externally visible eye organ $[6,7]$.

\subsection{Iris Recognition System Modules}

In Iris recognition system, the image of Iris will be passed and checked through (6) main steps which are illustrated below :

1. Acquisition of images: This phase takes an iris picture. By using cameras and sensors to capture sequences of the images of iris from the subject. An illumination, position and physical capture system are used for an image acquisition [8]. Factors affecting the image quality are number of pixels on the iris, lighting and occlusion. For the acquisition of images most of the iris systems require the cooperation of stern of the user. In order to increase flexibility Ketchantang proposed a method for obtaining the entire photo sequence during the enrollment, and selecting the most feasible pictures. Strong identity management supports registration $[9,10]$.

2. Pre-processing: Is the second module of Iris recognition, Preprocessing consists of a series of eyelid like pupil detection, iris liveness detection, the detection of iris boundary, and removal and normalization detection. The recognition of iris vitality distinguishes from photographing a live picture, glass eye or other object and video playback. Unlawfully forged and used may be the biometric characteristics. Several methods are used for locating the portions of iris and the pupil from the eye picture: Hough transformation, integral differential operator, gradient-based edge detection. Parabolic arcs are using to detect the eyes and delete the outlines of the upper and lower eyelids. The extracted area of iris must be mapped to a standardized form. Methods of iris location are based on spring strength, morphological operators, gradient, probability and moments. Zhaofeng had developed a method for iris location; it is depended on Hooke's law and on iteration regime of the spring force-driven. The center and radius of pupils and iris is determined by their composition of forces from all points [11]. Mira and Mayer applied morphological operators to achieve iris limits. The inward limit is distinguished by applying edge, picture opening, and closing operators. The external limit is recognized by applying edge, closing, and opening operators. The iris restriction strategy by Guodong Guo depends on force slope and surface distinction. The intensity gradient use integro differential operator. The Kullback-Leibler divergence is using to count the distance between two probability distributions got from the outer and inner areas. Moment-based texture segmentation algorithm proposed by L.A. Alexandre, where second order geometric moments of the image as texture features is used. The clustering algorithms such as K-means, self-organizing maps and fuzzy were using for segmenting the image to produce as output the clusters-labeled images [12-14].

3. Segmentation: The segmentation module determines pupil and limb borders and identifies the regions in which the eyelid and eyelid interrupt the outlines of the limb boundary (Fig. 2). Iris segmentation 
is a critical component of any iris detection system, because the imprecision with the location of the iris can seriously damage the system's fitness.

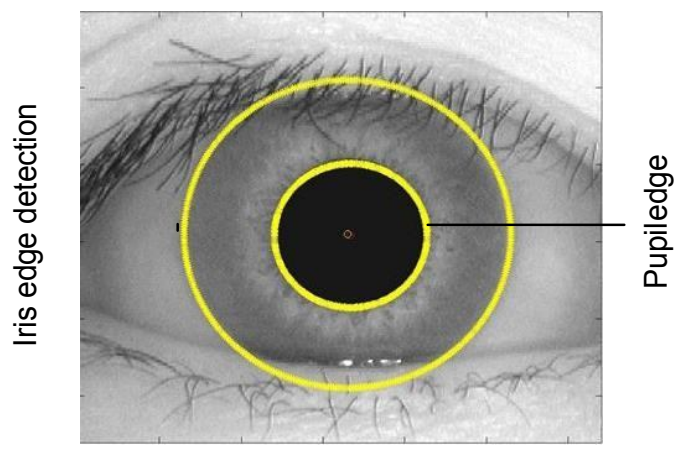

Fig. 2. Segmentation

4. Normalization: The normalization module uses a rubber sheet model for transforming the iris textures from Cartesian towards polar coordinates whenever the segmentation module has determined the boundary of the iris. The process is often called iris removal and results in a rectangular entity that is used for further processing. The three advantages of normalization are:

- It represents changing in pupil size because of external illumination changes that might affect the size of an iris.

- It is consistent that the irises of different individuals are mapped in common picture domains despite variations in pupil's size across subjects.

- Enable iris registration through a simple translation operation during the matching stage, which can account for rotations in the plane eye and head.

A binary mask is associated with each unwrapped iris which divides iris pixels (labeled "1") and pixels corresponding to pixels identified during segmentation (labeled with "0"). Following normalization, photometric transformations improve the texture of the unwrapped iris.

5. Extraction of function (encoding): noise removal from iris image is included in this phase with iris code generation. While the unwrapped iris can be used for a direct comparison with two irises (for example, by means of a correlation filter), most systems use a feature extraction routine in order to encode the texture of the iris. Encoding algorithms usually perform a cross- resolution analysis of the iris by using wavelet filters. 2D Gabor wavelet is used for the extraction of the local phasor information on the texture of Iris in a common encoding mechanism. The mechanism then codes each phazor response with two pieces, which leads to an IrisCode.

6. Classification and matching: By comparing the features of two iris images, the corresponding module generates a match score. The hamming distance, is a technique used for comparing two iris Codes which is the number of corresponding bits that differ between both two Iris Codes. The binary mask in the standardization module ensures that only bits matching valid iris pixels are compared. Before the Hamming distance is calculated by registration procedure, both iris codes must be aligned. While in most cases a simple translation procedure may be sufficient, more sophisticated schemes can accommodate the elastic change in texture of iris. Researchers have also developed other types of encoding and matching systems based on discrete cosine transformations, ordinary features, and scale - invariant transformations [11].

Stages of Iris recognition are showed on Fig. 3.

Iris recognition diagram are showed on Fig. 4.

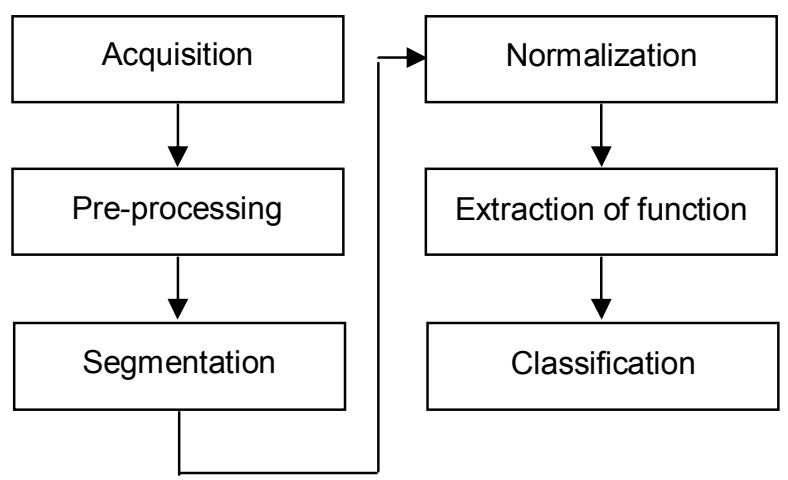

Fig. 3. Stages of Iris recognition

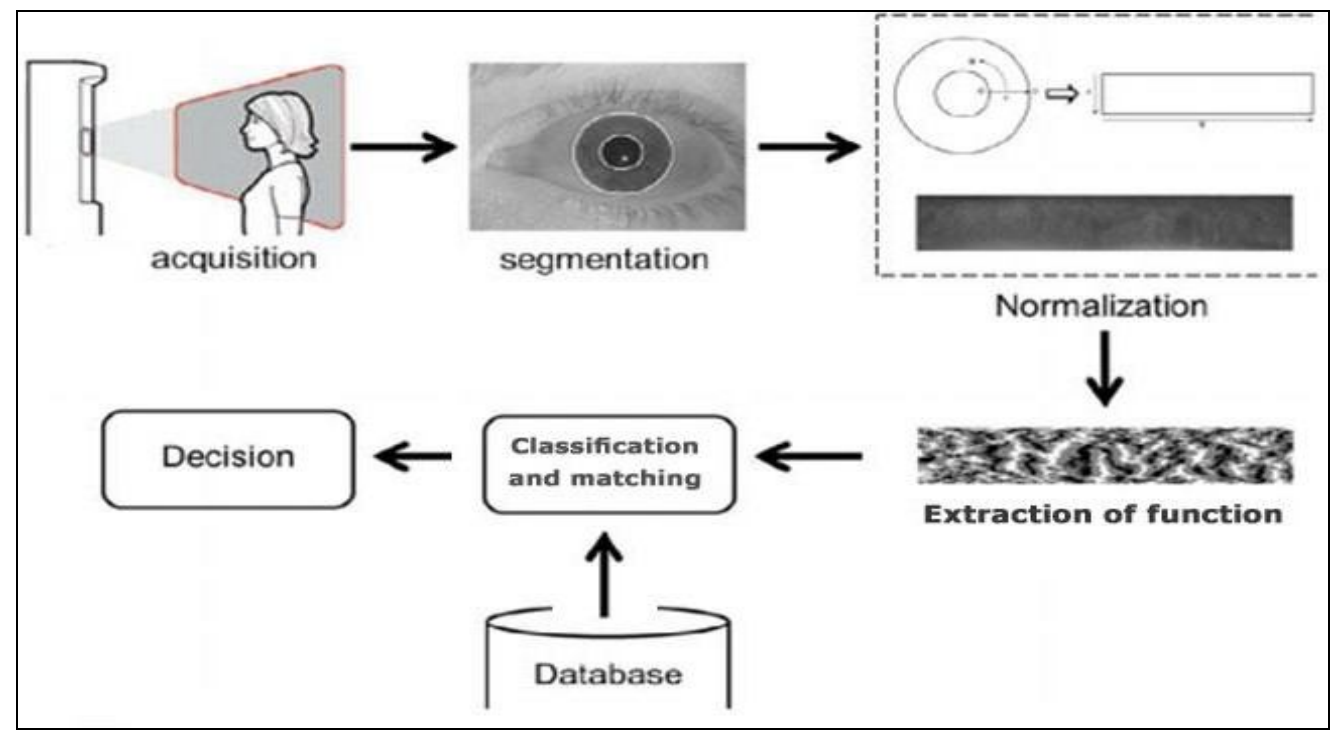

Fig. 4. Iris recognition diagram 


\section{Iris Recognition Methods}

The number of methods used to recognize iris is included in this section and is defined below [15]:

4.1 Zero Crossing Representation Method: It presents iris characteristics based on the null crossing transformation at varies resolution levels. The algorithm is invariant in translation, turn and size. In the images, a number of 1D signals are created based on the dyadic wavelet transformation and zero crossing images. The virtual circles are tamponed as circular from the center. The collected information is standardized and generates the same number of points and a zero-crossing representation from any virtual circle. The benefit of this feature is the reduction in the amount of calculation, as the amount of null crossing is below data.

4.2 Phase Base Method: This method is depending on the phase information and recognizes iris patterns. Information about the phase of the contrast of lighting and images is independent. Images of eye with an image focus evaluation were captured in real time with iris radius of $80-130$ pixels. The search results greatly limit the search for the pupil, they cannot be presumed to be concentrated. The center of pupils is very often nasal and lower than the center of the iris. It can have a radius of between and 0.8 iris. All three parameters that define a pupil circle should therefore be calculated separately from the iris parameters. The pupil's and iris limits were found with the operator of Integra differential.

4.3 Iris Authentication based On Continuous Dynamic Programming: The iris is authenticated by cinematic characteristics, speed. Beginning with the extraction of pupils, the highest summit is indicated in your histogram, which provides the thresholds with lower eye intensity values. The concept of the comparison of shape characteristics part wise is used for continuous dynamic programming.
4.4 Approach Based On Intensity Variations: As features are registered, the sharp variations in iris patterns. In the iris location stage, image projections in horizontal and vertical direction are used to measure the center coordinates of the student. The exact circles of iris and pupil parameters calculated by using the edge of canny detector and the Hough transformer. Gabor filter is built for the acquisition of the spatial domain frequency band. The Gaussian functions are moduled by circular sinusoidal functions. Gaussian function.

4.5 Texture-Analysis Based Method: Using a silicon-intensified target camera, high-quality images were recorded together with a standard image recorder and $512 \times 480$ pixels in resolution. The limit and pupil have circular contours that are extended up and down with parabola arcs to the upper and bottom eyes. By voting the edge points with Hough transformation, the contour parameter $\mathrm{x}, \mathrm{y}$ and radius are achieved. The iris contour is the biggest number of border points. The Laplacian Gaussian is used to the image in many ways, with laplacian pyramid construction.

\section{Conclusion}

Iris recognition has picked up a more noteworthy consideration because of its uniqueness, security throughout many years and the iris fashioning trouble.

This paper introduces the survey about different present strategies those are proposed by various creators.

The greater part of the arrangements pursue the 5 essential advances limitation of eye, picture division, standardization, highlight extraction and coordinating.

The Iris acknowledgment framework is a standout amongst the best secure strategies for validation.

The iris uniqueness and low likelihood of a bogus acknowledgment or mistake dismissal all add to the advantages of utilizing Iris acknowledgment innovation.

\section{REFERENCES}

1. Ranjan, S., Prabu, S., Swarnalatha P., Magesh, G. and Sundararajan, R. (2017), "Iris Recognition System", International Research Journal of Engineering and Technology, Vol. 4, No. 12, pp. 864-868.

2. Kundur, N., C and Prasad, M.R. (2018), "Iris recognition systems - A review", International Conference on Intelligent Computing and Control Systems, ISBN: 978-1-5386-2842-3.

3. Wildes,R. (1997) . "Iris recognition: an emerging biometric technology", Proceedings of the IEEE, p. 85.

4. Win, E. P. and Aye, N. (2014), "An Effective Iris Recognition System", International Conference on Advances in Engineering and Technology (ICAET'2014), Singapore.

5. Shah, N. and Shirnath, P. (2014), "Iris Recognition System - A Review", International Journal of Computer and Information Technology, Vol. 03, Issue 02, pp. 321-327.

6. Ghayoumi, M. (2015), “A review of multimodal biometric systems: Fusion methods and their applications", IEEE/ACIS 14th International Conference on Computer and Information Science (ICIS), pp. 131-136.

7. Hajari, K. and Bhoyar, K. (2015), “A review of issues and challenges in designing Iris recognition Systems for noisy imaging environment", International Conference on Pervasive Computing (ICPC), pp. 1-6.

8. Mahajan, S. and Mahajan, K. (2017), “A Survey on IRIS Recognition System: Comparative Study”, International Journal on Recent and Innovation Trends in Computing and Communication, Vol. 5, Issue. 4, pp. 238-242.

9. Kevin W. B., Karen, H. and Patrick, J. F. (2008), "Image Understanding for Iris Biometrics: A Survey", Computer Vision and Image Understanding, Vol. 110, Issue 2, pp. 281-307.

10. Ketchantang, W., Derrode, S., Bourennane, S. and Martin, L. (2005), "Video Pupil Tracking for Iris Based Identification", Advanced Concepts for Intelligent Vision Systems, LNCS 3708, pp. 1-8.

11. Harifi, S. and Bastanfard, A. (2015), "Previous works about iris recognition stages", IEEE: Forth International Conference on e-Technologies and Networks for Development (ICeND), ISBN: 978-1-4799-8451-0, DOI: 10.1109/ICeND.2015.7328530. 
12. Zhaofeng, H., Tieniu, T. and Zhenan, S. (2006), "Iris Localization via Pulling and Pushing”, International Conference on Pattern Recognition, pp. 366-369.

13. Mira, J. and Mayer, J. (2003), "Image feature extraction for application of biometric identification of iris: a morphological approach", IEEE Proc. XVI Brazilian Symposium on Computer Graphics and Image Processing, pp. 391-398.

14. Guodong, G. and Jones, M. J. (2008), "Iris extraction based on Intensity Gradient and Texture Difference", IEEE Workshop on Applications of Computer Vision, pp. 1-6.

15. Abhilash, A. K., Raghuwanshi, A. and Sharma, V. K. (2015), "Biometric System- A Review", International Journal of Co mputer Science and Information Technologies, Vol. 6 , No. 5, pp. 46.16-46.19.

Надійшла (received) 18.04.2019

Прийнята до друку (accepted for publication) 19.06.2019

\section{Відомості ПРО АвтоPIB / AвOUT тHE AUTHORS}

Амін Саліх Мохаммед - кандидат технічних наук, завідувач кафедри комп'ютерної інженерії, Lebanese French University, Ербіль, Курдистан, Ірак;

Amin Salih Mohammed - PhD, Associate Professor, Head of the Department of Computer Engineering, Lebanese French University, Erbil, Kurdistan Region, Iraq;

e-mail: kakshar@lfu.edu.krd; amin.mohammed@su.edu.krd; ORCID ID: https://orcid.org/0000-0002-2993-6182

Саравана Балайі Б. - доцент кафедри інформаційних технологій, Lebanese French University, Ербіль, Курдистан, Ірак; B. Saravana Balaji - Associate Professor, Department of Information Technology, Lebanese French University, Erbil, Kurdistan Region, Iraq; e-mail: saravanabalaji.b@lfu.edu.krd; ORCID ID: https://orcid.org/0000-0001-9077-1658

Хіва Абдулкарім Мавлоуд - аспірант кафедри інформаційних технологій, Lebanese French University, Ербіль, Курдистан, Ірак;

Hiwa Abdulkarim Mawlood - PG Student, Department of Information Technology, Lebanese French University, Erbil, Kurdistan Region, Iraq;

e-mail: hiwa@tarinnet.info; ORCID ID: https://orcid.org/0000-0002-1612-1996

\section{Концептуальний аналіз \\ систем розпізнавання райдужної оболонки ока}

\section{Амін Саліх Мохаммед, Саравана Балайі Б., Хіва Абдулкарім Мавлоуд}

А н от а ц і я. Біометрія - це надійна вимірювана фізична функція, як пароль. Біометрична структура автоматично надає ідентичність особистості людини на основі його унікальних особливостей. Розпізнавання райдужної оболонки один з фізіологічних способів, використовуваних для ідентифікації людини в групі, і $є$ однією з точних біометричних систем. У цій статті коротко розглядаються дослідження, проведені раніше, щодо системи розпізнавання райдужної оболонки, іï переваги і використанні в області інформаційних технологій і безпеки. Використання недорогого обладнання може допомогти розпізнавати райдужну оболонку відповідно до інших стандартів в контексті безпеки, так як вимоги до безпечної ідентифікації постійно змінюються. Так, райдужна оболонка ока людини дає феноменальну базу для ідентифікації. В останні роки були отримані результати, які стосуються отримання, відновлення, оцінці якості, стиснення зображень, поділу, зменшення шуму, нормалізації, видалення ознак, порівняно коду райдужної оболонки, пошуку в базі даних великого розміру, прикладним аспектам, оцінці, продуктивності в різних умовах і багаторазового використання біометрії в аспекті розвитку розпізнавання райдужних оболонок в декількох активних напрямках досліджень. Справжній матеріал являє собою основу розпізнавання райдужної оболонки і огляд сучасних методів в різних областях.

Ключов і слов а : райдужна оболонка людини; біометрія; безпеку; аутентифікація; розпізнавання райдужної оболонки.

\section{Концептуальный анализ}

\section{систем распознавания радужной оболочки глаза}

\section{Амин Салих Мохаммед, Саравана Балайи Б., Хива Абдулкарим Мавлоуд}

Ан нот цция. Биометрия - это надежная измеримая физическая функция, как пароль. Биометрическая структура автоматически предоставляет идентичность личности человека на основе его уникальных особенностей. Распознавание радужной оболочки - один из физиологических способов, используемых для идентификации человека в группе, и является одной из точных биометрических систем. В этой статье кратко рассматриваются исследования, проведенные ранее, касательно системы распознавания радужной оболочки, ее преимуществах и использовании в области информационных технологий и безопасности. Использование недорогого оборудования может помочь распознавать радужную оболочку в соответствии с другими стандартами в контексте безопасности, так как требования к безопасной идентификации постоянно меняются. Так, радужная оболочка глаза человека дает феноменальную базу для идентификации. В последние годы были получены результаты, относящиеся к получению, восстановлению, оценке качества, сжатию изображений, делению, уменьшению шума, нормализации, удалению признаков, сопоставлению кода радужной оболочки, поиску в базе данных большого размера, прикладным аспектам, оценке, производительности в различных условиях и многократному использованию биометрии в аспекте развития распознавания радужных оболочек в нескольких активных направлениях исследований. Настоящий материал представляет собой основу распознавания радужной оболочки и обзор современных методов в различных областях.

Ключевые слова: радужная оболочка человека; биометрия; безопасность; аутентификация; распознавание радужной оболочки. 